\title{
Tusk-bearing beaked whales from the Miocene of Peru: sexual dimorphism in fossil ziphiids?
}

\author{
Olivier Lambert,* Giovanni Bianucci, and KlaAs Post \\ Institut Royal des Sciences Naturelles de Belgique, Département de Paléontologie, Rue Vautier 29, B-1000 Brussels, \\ Belgium (OL) \\ Dipartimento di Scienze della Terra, Università di Pisa, via S. Maria 53, 1-56126 Pisa, Italy (GB) \\ Natuurhistorisch Museum Rotterdam, P.O. Box 23452, N-3001 Rotterdam, Netherlands (KP)
}

* Correspondent: olivier.lambert@naturalsciences.be

\begin{abstract}
New well-preserved fossils from Peru reveal details of the dentition and morphology of the mandible and rostrum in 2 late middle to early late Miocene beaked whales (Cetacea, Odontoceti, Ziphiidae). Apical mandibular tusks are present in both Nazcacetus urbinai and Messapicetus sp. In the former the tusks are associated with a strong reduction of the postapical dentition, whereas in Messapicetus sp. a complete series of functional upper and lower teeth is retained. The larger sample of Messapicetus sp. from a single locality and age reveals intraspecific variation in size and shape of the tusks and surrounding structures. In addition, the rostrum of Messapicetus displays thickened premaxillae, dorsally closing the mesorostral groove. By comparison with modern beaked whales, most of them highly sexually dimorphic at the level of the tusks and rostrum, we propose that the tusks of Messapicetus were used in intraspecific fights between adult males. Strengthening of the rostrum through the dorsal closure of its transverse section would have reduced the risk of fractures when facing impacts. DOI: 10.1644/08-MAMM-A-388R1.1.
\end{abstract}

Key words: beaked whale, intraspecific fights, Miocene, Peru, sexual dimorphism, tusks, Ziphiidae

(C) 2010 American Society of Mammalogists

In addition to their ability to dive to significant depths and their discreet behavior, sexual dimorphism is one of the striking features of extant beaked whales (suborder Odontoceti, family Ziphiidae). Adult males bear mandibular tusks, 1 pair in most species, often apical but posteriorly shifted and symphyseal in some species of Mesoplodon, but the considerably smaller tusks of the females usually remain impacted (Besharse 1971; Fraser 1942; MacLeod and Herman 2004; Moore 1968; Ross 1984 for data on sexual dimor phism of tusks and mandible). These tusks are used in intraspecific male-male fights (Heyning 1984; MacLeod $1998,2002)$. When raking the body of the opponent, the tusks cause scars, which remain unpigmented and visible throughout life (Heyning 1984; MacLeod 1998). The accumulation of scars is considered as an indicator of the male "quality" during social interactions (MacLeod 1998). Often tusks are associated with a mesorostral ossification of the vomer (mostly in the genera Mesoplodon and Ziphius), whereas in other species the bony mesethmoid sometimes partly fills the mesorostral groove (Berardius). In these cases the bones of the rostrum of adult males are thicker and denser (Besharse 1971; Fraser 1942; Heyning 1984; MacLeod and Herman 2004; Omura 1972; Reyes et al. 1991); it is proposed that this feature reduces the risk of fractures during fights (Heyning 1984; MacLeod 2002 (for the discussion of alternative functional interpretations of the dense rostrum in adult male Mesoplodon, see de Buffrénil and Casinos \{1995\} and Zioupos et al. \{1997\}]).

The fossil record of ziphiids remained poor for a long time. Most fossil species are described on the basis of isolated and sometimes fragmentary cranial remains, including robust and dense rostra, or isolated fragments of mandible displaying enlarged apical alveoli (Abel 1905; Bianucci 1997; du Bus 1868; Lambert 2005; Leidy 1877). The 1st skull-mandible association described for a fossil ziphiid involved Ninoziphius platyrostris de Muizon, 1983, a species from the Pliocene of Peru (de Muizon 1984). Unfortunately, the dorsal part of the rostrum of the holotype (and only described specimen) of this species is incomplete, and the mandibular apical teeth are lost. Recently, 2 new localities from the Miocene of Peru yielded skull-mandible associations for 2 additional ziphiid species: 1 specimen of Nazcacetus urbinai (Lambert et al. 2009) from

ww w. ma m malogy.org 


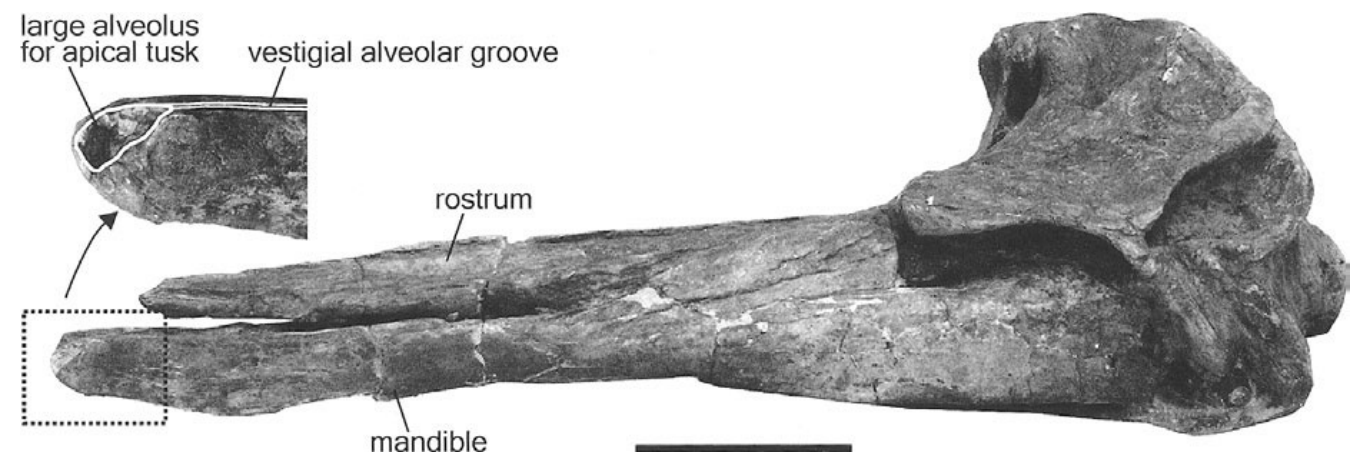

Fig. 1.-Left lateral view of the skull and associated mandible of Nazcacetus urbinai MUSM 949, Miocene of Peru, with a detail of the apical enlarged alveolus on the mandible. Scale bar $=100 \mathrm{~mm}$.

Cerro los Quesos, and an exceptional sample of 8 specimens of a new species of Messapicetus (Bianucci et al. 1992), 2 of them with the apical tusks in connection (Lambert et al. 2008; O. Lambert, pers. obs.), from Cerro Colorado. Some rare modern ziphiid species are known by an even smaller number of specimens (Dalebout et al. 2002, 2003). In the light of these new finds we investigate the evolution of tusks, the associated reinforcement of the rostrum, and sexual dimorphism in Miocene ziphiids.

\section{Materials and Methods}

Institutional abbreviations.--MUSM represents the Museo de Historia Natural, Universidad Nacional Mayor de San Marco, Lima, Peru; USNM, the United States National Museum of Natural History, Washington, D.C.; and IRSNB, the Institut Royal des Sciences Naturelles de Belgique, Bruxelies, Belgium.

Specimens--In addition to data from the literature and specimens from older collections, this work is based mostly on 2 fossil taxa. N. urbinai is known from 1 skull with the associated mandible and cervical vertebrae (MUSM 949), found in Cerro los Quesos, $50 \mathrm{~km}$ south of the city of Ica, on the coastal desert of southern Peru. Messapicetus sp. is known from 8 specimens found in Cerro Colorado, $35 \mathrm{~km}$ southwest of Ica: MUSM 950 and MUSM 951, fragmentary skulls with associated mandible elements; MUSM 1036, skull with associated mandible; MUSM 1037, skull with associated mandible and tusks; MUSM 1038, skull with associated mandible and tusk elements; MUSM 1394, fragmentary skull of a calf; MUSM 1481, skull; and MUSM 1482, anterior extremity of the rostrum and mandible. This unusually high concentration of specimens of Messapicetus sp. in a limited area and roughly the same horizon, including a calf, could indicate the proximity of a preferential feeding region for this species (Bianucci et al. 2008a). Because these disarticulated specimens were found in several beds representing shallowwater deposits and in association with a very diversified marine fauna (including other cetaceans, turtles, seabirds, and fishes), the assemblage of Cerro Colorado does not correspond to a mass-stranding event.
Strata from both localities belong to the lower part of the Pisco Formation, and are dated from late middle to early late Miocene, roughly between 14 and 10 million years ago (DeVries 1998; Dunbar et al. 1990). Preliminary phylogenetic analyses suggest that Messapicetus belongs to the subfamily Ziphiinae (including the extant species Ziphius cavirostrisBianucci et al. 1994; Lambert 2005), whereas the affinities of Nazcacetus are not completely solved. Nevertheless, the latter is positioned similarly among crown-ziphiids (Lambert et al. 2009).

\section{Results}

Tusks and surrounding structures on the mandible.-One or 2 pairs of enlarged anterior alveoli often have been reported on isolated fossil mandibular fragments, generally without tusks found in situ (Abel 1905; de Muizon 1984; True 1907), except for a few occasions (e.g., Bianucci 1997; Capellini 1885; Whitmore and Kaltenbach 2008). The more complete $N$. platyrostris and $N$. urbinai (clearly identified as ziphiids based on the architecture of the skull, particularly the diagnostic vertex, the hamular process of the pterygoid, and the periotic) both display enlarged apical alveoli, confirming that some fossil ziphiids possessed tusks (de Muizon 1984; Lambert et al. 2008, 2009; Fig. 1).

One particularly interesting specimen of Messapicetus sp. (MUSM 1037) displays a finely preserved pair of complete, in situ, apical mandibular tusks that are located anterior to the end of the rostrum and project outside the mouth (Figs. 2 and 3). These teeth have short crowns ( $9 \mathrm{~mm}$ long) and large, swollen, and transversely flattened roots that have maximum and minimum diameters (at the level of the alveolus) of 28 and $15 \mathrm{~mm}$. Crowns are straight, not medially curved as in postapical teeth (see below). Roots are significantly more robust than roots of postapical teeth (in postapical teeth the transverse minimum diameter ranges from 5.0 to $11.8 \mathrm{~mm}$, for a maximum diameter ranging from 8.1 to $26.4 \mathrm{~mm}$ ). Each apical tooth is directed anterodorsally, with a slight Iateral inclination. A longitudinal bony crest separates medially left and right teeth. This crest thickens strongly anteriorly, forming a robust apical median protuberance, slightly longer than the 

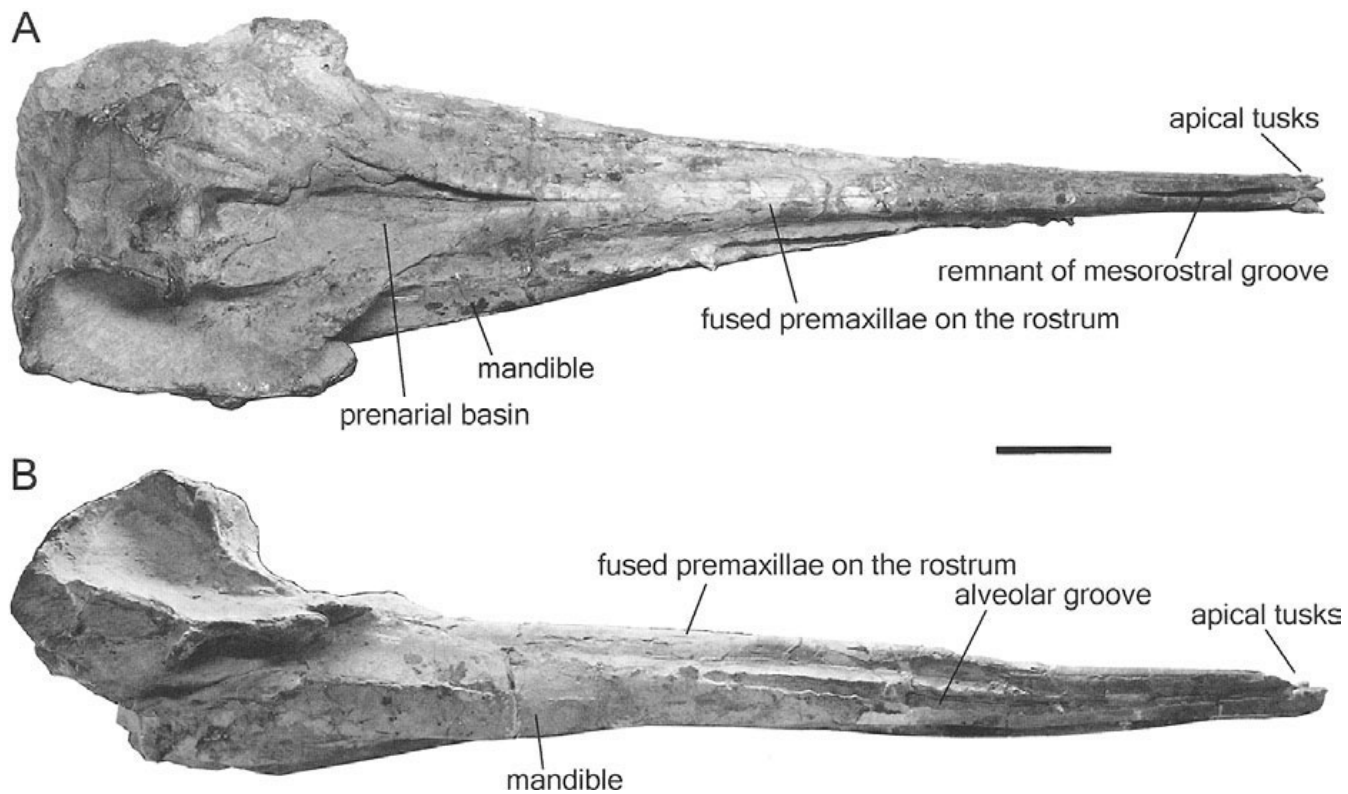

Fig. 2.--Skull and associated mandible of Messapicetus sp. MUSM 1037, Miocene of Peru. A) Dorsal view. B) Right lateral view. Scale bar $=100 \mathrm{~mm}$.

tusks anteriorly. Posterior to the teeth the longitudinal crest raises and widens to form the thick anterior margin of a concave area that fits tightly against the apex of the rostrum. A similar concavity is observed on the dorsal surface of the mandible of $Z$. cavirostris, with the upheaval of the anterior margin specially developed in adult males (Fig. 4).

In contrast to Nazcacetus, which displays only tiny postapical teeth likely originally embedded in the gum (Lambert et al. 2009), functional postapical teeth are retained in Messapicetus sp. These teeth show a distinct wear of the apex (the tips of teeth are regularly truncated, with a flat distal surface) and anterior-posterior margin of the crown (clear occlusion grooves), indicating, respectively, contact with food and opposing teeth. On the mandible these teeth are separated from apical tusks by a long diastema, as seen in Tasmacetus shepherdi, the only extant ziphiid retaining functional postapical teeth. The symphyseal portion of the mandible is long (38-42\% of the mandible length) and robust, with a halfcircular section.

The Peruvian sample for Messapicetus sp. is the 1st for fossil ziphiids to demonstrate intraspecific variation in the anterior portion of the mandible (Figs. 5A and 5B). In the finely preserved MUSM 1038 apical alveoli are smaller $(23 \times$ $12 \mathrm{~mm}$ ), the anteromedial bony protuberance is much weaker, and the upheaval anteriorly limiting the cavity for the rostrum apex is not as developed as in MUSM 1037. In the more fragmentarily preserved MUSM 1482 alveoli are much larger and asymmetric (respectively $18 \times 33$ and $24 \times 35 \mathrm{~mm}$ for

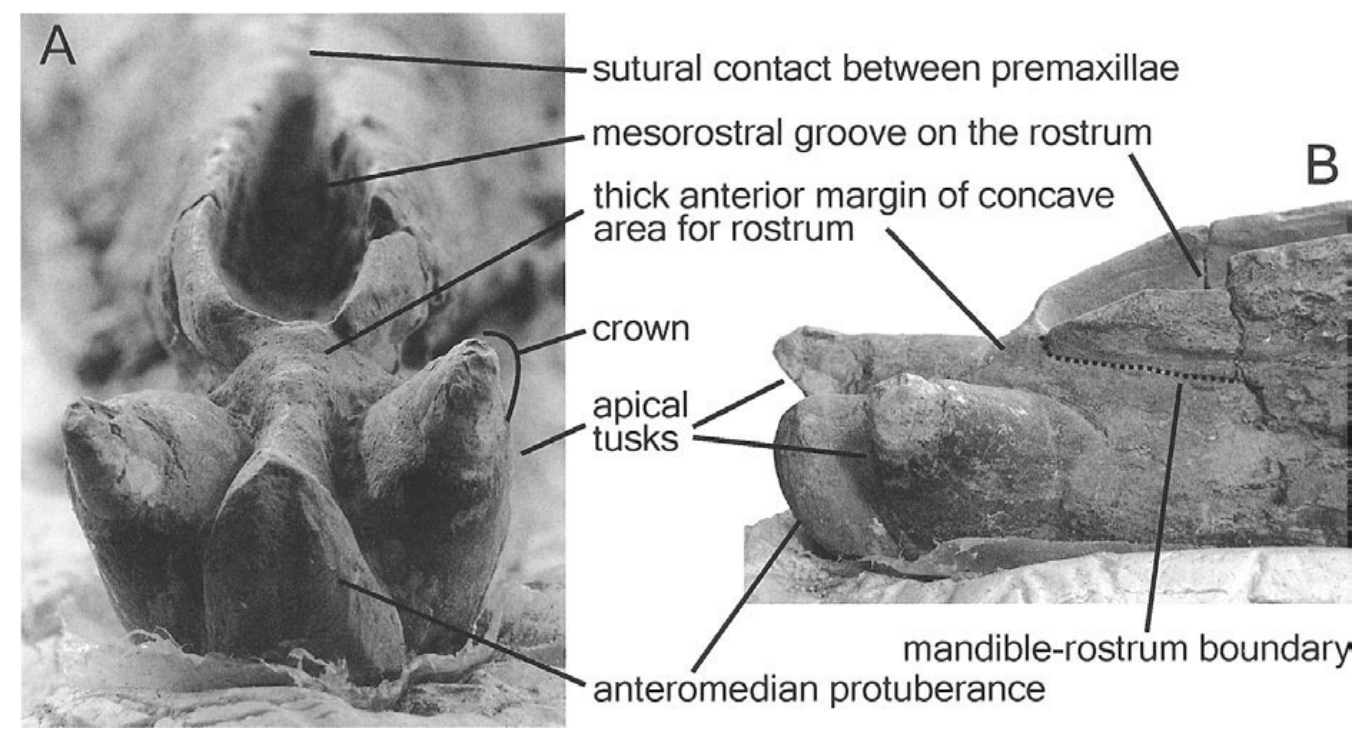

Fig. 3.-Detail of the anterior end of the mandible and rostrum of Messapicetus sp. MUSM 1037, Miocene of Peru, displaying apical tusks and surrounding bony structures. A) Anterior view. B) Lateral (slightly anterior) view. 


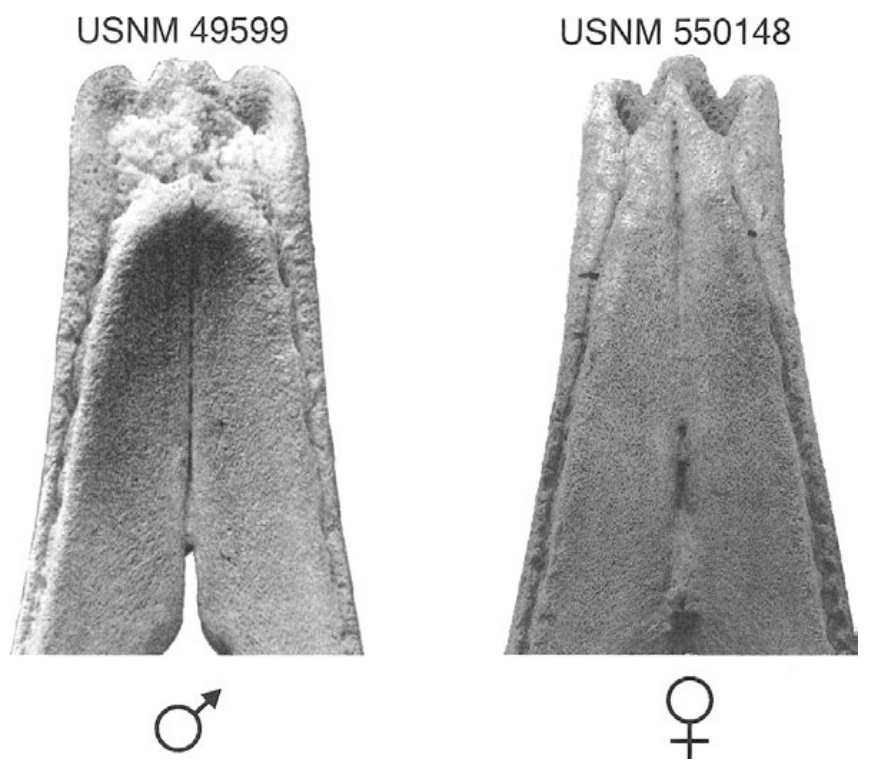

Fig. 4.-Dorsal view of the anterior part of the mandible of adult male (USNM 49599, modified from True [1910:plate 23]) and adult female (USNM 550148) of Ziphius cavirostris. The male bears larger apical alveoli on a more-robust anterior end of the mandible. Specimens not to scale; size adjusted for a same symphyseal length.

right and left alveoli) and the anteromedial bony protuberance is even stronger than in MUSM 1037. The enlargement of the alveoli in MUSM 1482 further stresses the robustness of the anterior portion of the mandible, displaying a distinct distal widening and deepening not as pronounced in MUSM 1037 and absent in MUSM 1038 (Fig. 5C).

Rostrum--Several fossil ziphiid species share with members of the extant genera Mesoplodon and Ziphius a filling of the mesorostral groove of the rostrum by the dense vomer (see Bianucci et al. [2007, 2008b] for various species from the Neogene of South Africa). Unfortunately, none of these species is known on the basis of skull-mandible associations. In $N$. platyrostris the dorsal part of the rostrum of the holotype is strongly worn, but no peculiar development of the vomer is seen. The mesorostral groove of the holotype of N. urbinai is hollow-the classical condition in odontocetes other than ziphiids--and the rostrum is rather slender. This condition could indicate that this individual was either immature or a female (Lambert et al. 2009), but a larger sample is needed to be certain.

Members of the genus Messapicetus are characterized by a very elongated rostrum, 3 times the length of the cranium (Bianucci et al. 1994), proportionally the longest in ziphiids. In all the specimens of Messapicetus sp. and the Italian species $M$. longirostris Bianucci et al., 1992, the groove is not filled by the vomer; instead it is covered dorsally by a dorsomedial development of the considerably thickened premaxillae (Figs. 2 and 6). The premaxillae display a sutural contact for more than one-half of the rostrum length, the rostrum being open only dorsally in the more slender anterior portion and in the prenarial basin. The robust section of the joined premaxillae is anteriorly half-circular and becomes more triangular toward the prenarial basin. Sections of the thick dorsomedially joined premaxillae were illustrated in $M$. longirostris (Bianucci et al. 1992) and through computed tomography scans of a fragmentary rostrum from the late Miocene of Maryland referred to cf. Messapicetus (Fuller and Godfrey 2007). On the most anterior section provided by Fuller and Godfrey (2007) the suture between the premaxillae is nearly invisible, possibly due to the high degree of ankylosis. Variation in this character among adult specimens from Cerro Colorado could not be quantified because of the incompleteness of some specimens and the poorly preserved rostrum of others. However, the specimen MUSM 1394, interpreted as a calf (based of the proportionally shorter rostrum, the partly ossified premaxillary crests on the vertex, and the presence of distinct parietals on the vertex), bears distinctly thinner premaxillae on the rostrum. At the posterior limit of the contact between left and right premaxillae each bone is $6 \mathrm{~mm}$ thick in MUSM 1394 versus $11 \mathrm{~mm}$ in the adult MUSM 951.

A homologous dorsal closure of the mesorostral groove by premaxillae has been described in several species from late Miocene-early Pliocene of the North Sea, including Bene-
A

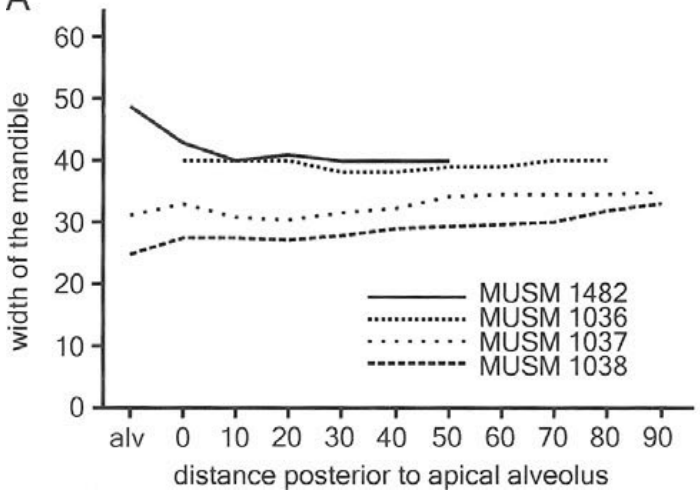

B

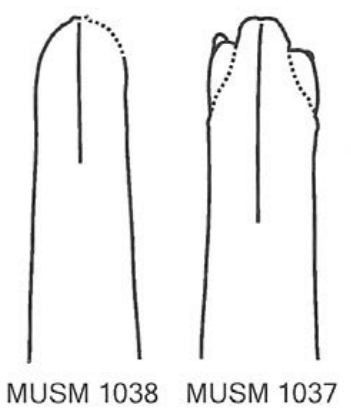

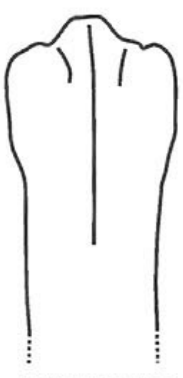

MUSM 1482
$\mathrm{C}_{1}$

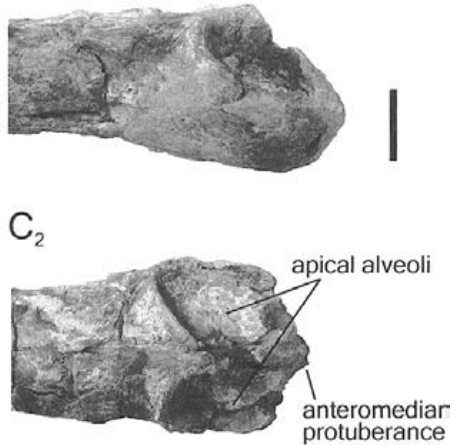

FIG. 5.-Variation in size and shape of the anterior part of the mandible in Messapicetus $\mathrm{sp}$. A) Changing width of the mandible from the level of apical alveoli in 4 specimens (in $\mathrm{mm}$ ). B) Ventral view of the anterior end of the mandible in 3 specimens, all at the same scale (MUSM 1482 is possibly an adult male). $C_{1}$ ) Lateral view of the anterior end of the mandible of MUSM 1482, $C_{2}$ ) Dorsal view of the same specimen. Scale bar $=20 \mathrm{~mm}$. 


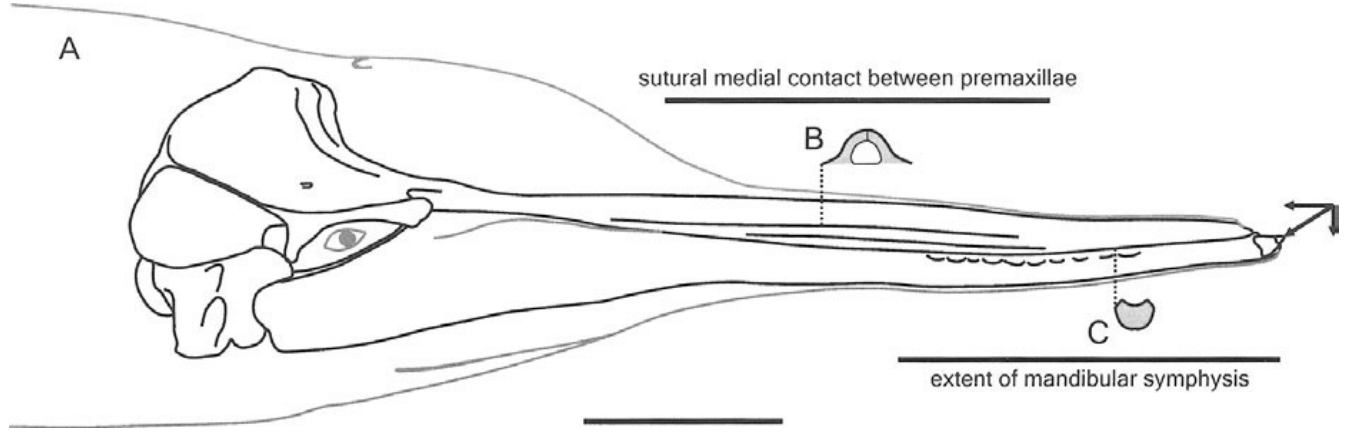

Frg. 6.-A) Reconstruction of the skull and mandible of Messapicetus sp. in lateral view, mostly based on MUSM 1037, except for the basicranium based on MUSM 1481. Extent of the symphyseal portion of the mandible and sutural dorsomedial contact of the premaxillae on the rostrum are indicated by thick lines. Arrows on the apex of the snout symbolize the force exerted on apical tusks during contact with the body of an opponent and its horizontal and vertical components. B) Section of dorsal portion of rostrum, based on MUSM 1037. Shape and size of the mesorostral opening at this level are based on computed tomography scan of a rostrum identified as cf. Messapicetus from late Miocene of Maryland provided by Fuller and Godfrey (2007). C) Section of mandible in the symphyseal portion, based on MUSM 1038. Scale bar $=$ $200 \mathrm{~mm}$.

ziphius brevirostris (Lambert, 2005), Choneziphius planirostris (Cuvier, 1823), and Ziphirostrum marginatum (du Bus, 1868; Fig. 7). In these species premaxillae are even thicker than in Messapicetus, especially in B. brevirostris and C. planirostris where the remaining mesorostral canal is nearly completely occluded. Some variation at the level of the development of the premaxillae is observed in $C$. planirostris and $Z$. marginatum. For example, Z. marginatum IRSNB M. 537 bears much thicker premaxillae anterior to the prenarial basin than do other specimens (maximum height of premaxilla on rostrum $=4 \mathrm{l}$ versus $17 \mathrm{~mm}$ in IRSNB M.1877), and larger specimens of $C$. planirostris have a proportionally deeper rostrum.

\section{Discussion}

The most obvious hypothesis for the function of apical mandibular tusks in Nazcacetus, Ninoziphius, and Messapice- tus is their use in fights between adult males, as is proposed for most extant ziphiids. Although fights between adult males have not been observed, fighting is inferred from the presence of numerous pairs of unpigmented linear scars on their bodies (Heyning 1984; MacLeod 1998). Considering the variation of size of the alveoli observed in mandibles of Messapicetus sp., we hypothesize that larger alveoli, originally holding larger teeth, correspond to adult males (e.g., MUSM 1482), a condition observed in most extant ziphiids. For example, in $Z$. cavirostris we observed an increase of size of apical alveoli, with a lower distance between alveoli and a wider and deeper apex of the mandible, in adult males (Fig. 4). Such a sexual dimorphism in Messapicetus would constitute strong support for an analogous use of teeth in intraspecific fights.

As in several extant ziphiids (see discussion in MacLeod and Herman [2004] for Mesoplodon bidens and M. densirostris), the bony structures surrounding the apical teeth also

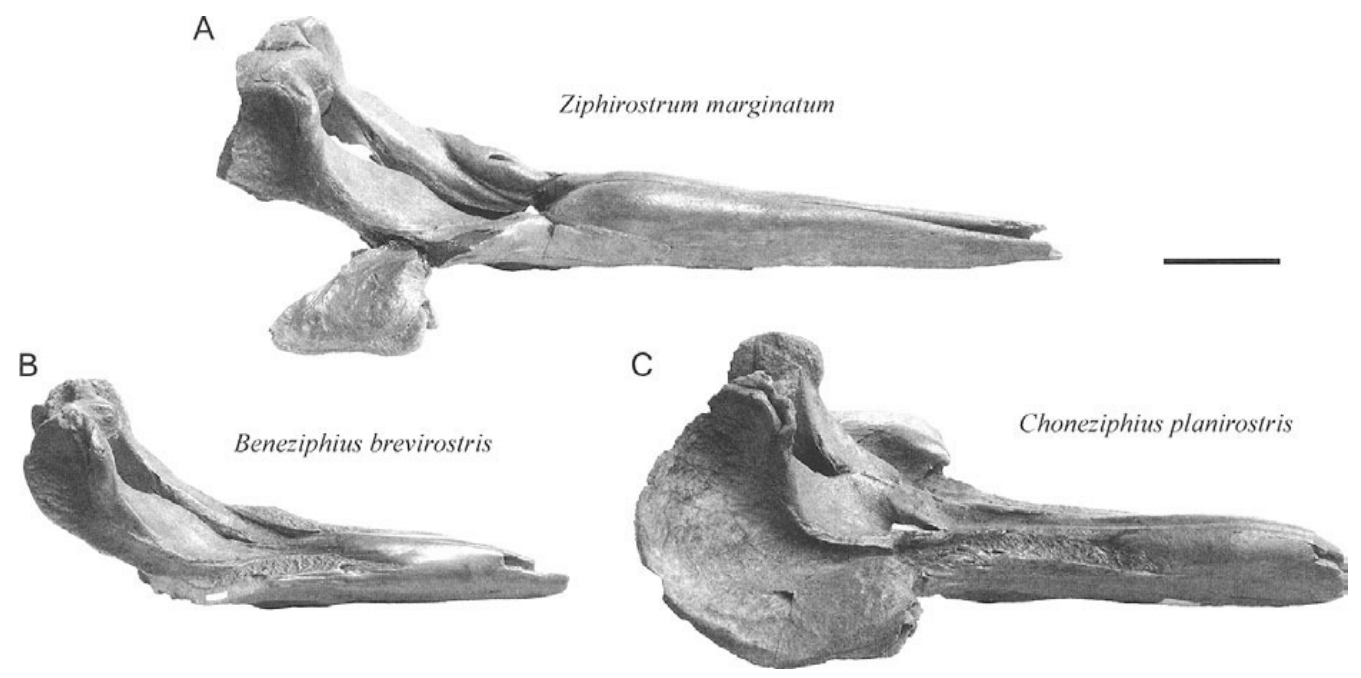

Fig. 7,--Dorsolateral view of the partial skull of various ziphiids from the late Miocene-early Pliocene of the North Sea displaying a dorsomedial suture of the thick premaxillae above the mesorostral groove. A) Ziphirostrum marginatum IRSNB M.537, B) Beneziphius brevirostris IRSNB M.1885, and C) Choneziphius planirostris IRSNB M.1881. Scale bar $=100 \mathrm{~mm}$. 
display variation interpreted as sexual dimorphism. From a functional point of view the apical medial bony protuberance precludes contact between the body of the opponent and the tusks in a direction parallel to the axis of the rostrum, limiting the risk of impact (and potential damage) on tusks from a direction oblique to their orientation. Posterior shift of the tusks in some species of Mesoplodon (Moore 1968) could correspond to another solution for preventing frontal impacts on the obliquely oriented teeth (Heyning 1984).

Posterior to the tusks of Mersapicetus sp., upheaval of the anterior margin of the concave area housing the apex of the rostrum, a feature that also is present in Ninoziphius, increases the contact area between mandible and rostrum. This condition possibly helps to keep the mouth closed during oblique impacts, thanks to the curved, instead of planar, surface of contact between the 2 elements. It further forms a buffer, which might transmit a part of the force of impacts directly to the rostrum (longitudinal component; see below). A similar function might apply to the deep concavity in the upper surface of the dorsally curved apex of the mandible in adult male Ziphius. Furthermore, the diastema separating the apical tusks from other teeth in Messapicetus and Ninoziphius allows a smoother contact between rostrum and mandible than if teeth were present. The tight fit of the mandible and rostrum is stressed by a clear taphonomic observation: in 6 of the 8 specimens of Messapicetus the mandible was found in connection with the rostrum, whereas postcranial skeleton was lost. Such a condition is found only rarely in fossil odontocetes (Bianucci et al. 2008a).

As mentioned above, except in the calf, we could not detect variation in the development of premaxillae on the rostrum of Messapicetus, atthough the variation observed in closely related species ( $C$. planirostris and $Z$. marginatum) might correspond to sexual dimorphism. We propose here that the thickening and elevation of the premaxillae, dorsally closing the mesorostral groove with a medial sutural contact in Messapicetus, strengthen the rostrum. The force exerted on apical tusks and the end of the rostrum when contacting the body of an opponent can be split into its vertical, longitudinal, and transverse components (Fig. 6). Vertical and probably minor transverse components produce a bending of the rostrum-mandible set, whereas the longitudinal component produces compression. The shift from a roughly U-shaped section of the rostrum to an $\mathrm{O}$-shaped section clearly makes this structure mechanically stronger. Closure of the section increases the rigidity, especially against transverse bending, compression, and torsion. Additionally, the half-circular shape of the section of premaxillae limits the number of mechanically weak corners and therefore further decreases the risk of fracture. It is noteworthy that the robust symphyseal portion of the mandible, similarly half-circular in section, provides a ventral reinforcement for the relatively slender anterior portion of the rostrum.

We propose that dorsomedial development of premaxillae above the mesorostral groove constitutes an alternative solution to the mesorostral ossification of the vomer observed in several extant ziphiids. It is much likely lighter than a complete filling of the groove, particularly for animals with such an elongated rostrum as Messapicetus. Strengthening of the rostrum goes farther in 2 . marginatum, and even more in C. planirostris, which displays a more massive but considerably shorter rostrum (Fig. 7).

The long-snouted Messapicetus and the geologically younger Ninoziphius retain a series of functional maxillary and dentary teeth, whereas the development of tusks in Nazcacetus and in most extant ziphiids (except Tasmacetus) is associated with the loss of other functional teeth. This observation modifies somewhat the scenario proposed for development of tusks in several odontocete lineages, which suggests that a change of diet from fish to cephalopods (suction replaces the teeth for catching and swallowing the prey so the teeth are freed from their food-processing function) was followed by development of tusks for aggressive social interactions (MacLeod 1998; Werth 2000). Here we show that some teeth remained functional for food processing in several fossil ziphiid lineages, whereas others were modified into tusks, as in Tasmacetus.

To summarize, we propose that the apical mandibular tusks of the long-snouted Messapicetus, described for the Ist time in a well-preserved fossil ziphiid, were used in intraspecific combat between adult males. This hypothesis is supported by the variation we observed in development of the apical alveoli and surrounding structures in the Peruvian sample and interpreted as secondary sexual characters. We also provide a functional interpretation for the peculiar morphology of the apex of the mandible that is in line with the hypothesized use of the tusks. We further suggest that dorsal closure of the mesorostral groove on the rostrum, by means of a sutural contact between the thickened premaxillae, leads to strengthening of the rostrum that is functionally equivalent, but likely lighter, than the filling of the groove by the vomer in various fossil and extant ziphiid species. Therefore, adult male Messapicetus were well-equipped to inflict linear wounds to their rivals. If the resulting scars remained unpigmented, as in modern ziphiids, they could provide an honest signal of the ability of a male to withstand combat. Besides the development of dimorphic tusks, Messapicetus retained functional postapical teeth, differing on that point from all but 1 extant species.

\section{RESUMEN}

Nuevos fósiles procedentes de Perú, en gran estado de conservación, revelan detalles de la dentición, morfología de la mandíbula y del rostro en dos ballenas picudas (Cetacea, Odontoceti, Ziphiidae) del Mioceno medio tardío al Mioceno tardío temprano. Los colmillos apicales de la mandíbula están presentes tanto en Nazcacetus urbinai como en Messapicetus sp. En el primero, los colmillos están asociados con una fuerte reducción de la dentición postapical, mientras que en Messapicetus sp., se mantiene la serie completa de dientes funcionales, superiores e inferiores. La gran muestra de 
Messapicetus sp., procedente de una sola edad y localidad, revela variación intraespecífica en el tamaño y forma de los colmillos y estructuras asociadas. Asimismo, el rostro de Messapicetus muestra un premaxilar engrosado, que dorsalmente encierra el surco mesorostral. De acuerdo a lo observado en ballenas picudas modernas, muchas de ellas altamente dimórficas a nivel de los colmillos y el rostro, proponemos que los colmillos de Messapicetus eran utilizados en confrontaciones intraespecíficas protagonizadas por machos adultos. El reforzamiento de la sección transversal del rostro mediante la obturación de su porción dorsal podría haber reducido el riesgo de fracturas ante posibles impactos.

\section{ACKNOWLEDGMENTS}

In addition to data from literature mentioned in the text, numerous observations on extant ziphiids were taken on specimens of various collections: Institut Royal des Sciences Naturelles de Belgique, Brussels, Belgium; Museo de Historia Natural, Universidad Nacional Mayor de San Marco, Lima, Peru; Museo di Storia Naturale e del Territorio, Università di Pisa, Pisa, Italy; Museo di Zoologia, Università di Firenze, Firenze, Italy; Muséum National d'Histoire Naturelle, Paris, France; Nationaal Natuurhistorisch Museum Naturalis, Leiden, Netherlands; Iziko South African Museum, Cape Town, South Africa; United States National Museum of Natural History, Washington, D.C.; and Zoölogisch Museum Amsterdam, Amsterdam, Netherlands. The abstract was translated into Spanish by $R$. Salas Gismondi. We thank P. Agnelli, J. G. Mead, C. de Muizon, G. Lenglet, E. Palagi, C. Potter, A. Rol, R. Salas Gismondi, and H. van Grouw for access to the collections under their care; M. Urbina Schmitt for fieldwork and discovery of most of the specimens studied in this work; W. Aguirre, R. Salas Gismondi, and M. Urbina Schmitt for preparation of specimens; B. M. Allen, M. D. Hardy, C. D. MacLeod, and J. G. Mead for the literature and information provided on extant beaked whale sexual dimorphism; A. Lorenzi for technical comments on the resistance of materials; and 2 anonymous reviewers and associate editor E. R. Dumont for their constructive remarks. The work of OL at the IRSNB is financially supported by Research Project MO/36/016 of the Belgian Federal Science Policy Office.

\section{Literature Cited}

ABEL, O. 1905. Les Odontocètes du Boldérien (Miocène supérieur) des environs d'Anvers. Mémoires du Musée Royal d'Histoire Naturelle de Belgique 3:1-155.

Besharse, J. C. 1971. Maturity and sexual dimorphism in the skull, mandible, and teeth of the beaked whale, Mesoplodon densirostris. Journal of Mammalogy 52:297-315.

Bianucci, G. 1997. The Odontoceti (Mammalia Cetacea) from Italian Pliocene. The Ziphiidae. Palaeontographia Italica 84:163-192.

Bianucci, G., O. Lambert, and K. Post. 2007. A high diversity in fossil beaked whales (Odontoceti, Ziphiidae) recovered by trawling from the sea floor off South Africa. Geodiversitas 29:561618.

Blanucci, G., O. Lambert, K. Post, and M. Urbina. 2008a. A new marine vertebrate assemblage from the Miocene of the Pisco Formation (Peru). Pp. 70-72 in Riassunti dei lavori (R. Mazzei et al., eds.). VIII edizione. Giornate di Paleontologia, Simposio della Società Paleontologica Italiana, Siena, 9-12 settembre 2008. Academia dei Fisiocritici, Siena, Italy.
Blanuccl, G., W. Landini, and A. Varola. 1992. Messapicetus longirostris, a new genus and species of Ziphiidae (Cetacea) from the late Miocene of "Pielra Leccese" (Apulia, Italy). Bolletino della Società Paleontologica Italiana 31:261-264.

BianuCC1, G., W. Landin, And A. Varola. 1994, Relationships of Messapicetus longirostris (Cetacea, Ziphiidae) from the Miocene of South Italy. Bolletino della Società Paleontologica Italiana 33:231-241.

Bianucci, G., K. Post, and O. Lambert, 2008b. Beaked whale mysteries revealed by seafloor fossils trawled off South Africa. South African Journal of Sciences 104:140-142.

CapelliN], G. 1885. Resti fossili di Dioplodon e Mesoplodon. Memoric della Regia Accademia delle Scienze dell'Istituto di Bologna 6:291-306.

Cuvier, G. 1823. Recherches sur les ossements fossiles, 5 (1ère partie). G. Dufour et E. D'Ocagne, Paris, France.

Dalebout, M. L., J. G. Mead, C. S. Baker, A. N. Baker, and A. L. VAN HELDEN. 2002. A new species of beaked whale Mesoplodon perrini sp. n. (Cetacea: Ziphiidae) discovered through phylogenetic analyses of mitochondrial DNA sequences. Marine Mammal Science 18:577-608.

Dalebout, M. L., ET AL. 2003. Appearance, distribution, and genetic distinctiveness of Longman's beaked whale, Indopacetus pacificus. Marine Mammal Science 19:421-461.

DE BUFFRÉNIL, V., AND A. CÁsinos. 1995. Observations histologiques sur le rostre de Mesoplodon densirostris (Mammalia, Cetacea, Ziphiidae): le tissu osseux le plus dense connu. Annales de Sciences Naturelles, 13ème série 16:21-32.

DE Murzon, C. 1983. Un Ziphiidae (Cetacea) nouveau du Pliocène inférieur du Pérou. Comptes Rendus de l'Académie des Sciences de Paris 297:85-88.

DE Muizon, C. 1984. Les vertébrés de la Formation Pisco (Pérou). Deuxième partie: les Odontocètes (Cetacea, Mammalia) du Pliocène inférieur du Sud-Sacaco. Travaux de l'Institut Français d'Etudes Andines 27:1-188.

DeVRles, T. 1998. Oligocene deposition and Cenozoic sequence boundaries in the Pisco Basin (Peru). Journal of South American Earth Sciences 11:217-231.

Du Bus, B. A. L. 1868. Sur différents Ziphiides nouveaux du Crag d'Anvers. Bulletin de l'Académie Royale des Sciences, des Lettres et des Beaux-Arts de Belgique 25:621-630.

Dunbar, R. B., R. C. Marty, and P. A. Baker. 1990. Cenozoic marine sedimentation in the Sechura and Pisco basins, Peru. Palaeogeography, Palaeoclimatology, Palaeoecology 77:235-261.

Fraser, F. C. 1942. The mesorostral ossification of Ziphius cavirostris. Proceedings of the Zoological Society of London, B. Systematic and Morphological 112:21-30.

Fuller, A. J., AND S. J. Godfrey. 2007. A late Miocene ziphiid (Messapicetus sp.: Odontoceti: Cetacea) from the St. Marys Formation of Calvert Cliffs, Maryland. Journal of Vertebrate Paleontology 27:535-540.

Heyning, J. E. 1984. Functional morphology involved in intraspecific fighting of the beaked whale, Mesoplodon carlhubbsi. Canadian Jourral of Zoology 62:1645-1654.

LAMBERT, O. 2005. Systematics and phylogeny of the fossil beaked whales Ziphirostrum du Bus, 1868 and Choneziphius Duvernoy, 185. (Cetacea, Odontoceti), from the Neogene of Antwerp (North of Belgium). Geodiversitas 27:443-497.

Lambert, O., G. BianucCi, and K. Post. 2009. A new beaked whale (Odontoceti, Ziphiidae) from the middle Miocene of Peru. Journal of Vertebrate Paleontology 29:910-922. 
Lambert, O., G. Blanucci, K. Post, aird M. Urbina. 2008. Tuskbearing beaked whales from the Miocene of Peru. Journal of Vertebrate Paleontology 28:103A.

LEIDY, J. 1877. Description of vertebrate remains, chiefly from the Phosphate Beds of South Carolina. Journal of the Academy of Natural Sciences of Philadelphia 8:209-261.

MACLEOD, C. D. 1998. Intraspecific scarring in odontocete cetaceans: an indicator of male 'quality' in aggressive social interactions? Journal of Zoology (London) 244:71-77.

MACLEOD, C. D. 2002. Possible functions of the ultradense bone in the rostrum of Blainville's beaked whale (Mesoplodon densiros tris). Canadian Journal of Zoology 80:178-184.

MacLeod, C. D., AND J. S. Herman. 2004. Development of tusks and associated structures in Mesoplodon bidens (Cetacea, Mammalia). Mammalia 68:175-184.

MOORE, J. C. 1968. Relationships among the living genera of beaked whales. Fieldiana: Zoology 53:209-298.

OMURA, H. 1972. An osteological study of the Cuvier's beaked whale, Ziphius cavirostris, in the northwest Pacific. Scientific Reports of the Whales Research Institute 24:1-34.

Reyes, J. C., J. G. Mead, AND K. VAN Waerebeek. 1991. A new species of beaked whale Mesoplodon perwvianus sp. $\mathrm{n}$. (Cetacea: Ziphiidae) from Peru. Marine Mammal Science 7:124.
Ross, G. J. B. 1984. The smaller cetaceans of the south east coast of southern Africa. Annals of the Cape Provincial Museums of Natural History 15(2):173-410.

True, F. W. 1907. Observations on the type specimen of the fossil cetacean Anoplonassa forcipata Cope. Bulletin of the Museum of Comparative Zoology 51(4):95-106.

True, F. W. 1910. An account of the beaked whales of the family Ziphiidae in the collection of the United States National Museum, with remarks on some specimens in other American museums. Bulletin of the United States National Museum 73:1-89.

WERTH, A. J. 2000. Feeding in marine mammals. Pp. 487-526 in Feeding: form, function, and evolution in tetrapod vertebrates (K. Schwenk, ed.). Academic Press, San Diego, California.

Whitmore, F. C., and J. A. Kaltenbach, 2008. Neogene Cetacea of the Lee Creek Phosphate Mine, North Carolina. Virginia Museum of Natural History Special Publication 14:181-269.

Zioupos, P., J. D. Currey, A. Casinos, And V. de BuffrénIl. 1997. Mechanical properties of the rostrum of the whale Mesoplodon densirostris, a remarkably dense bony tissue. Journal of Zoology (London) 241:725-737.

Submitted 17 December 2008. Accepted 21 April 2009.

Associate Editor was Elizabeth R. Dumont. 